\title{
New Spectrophotometric Methods for the Quantification of Bumetanide Tablets
}

\section{Mukthinuthalapati Mathrusri Annapurna*, Raghu Raj Naik and Sistla Mounica Pratyusha}

Department of Pharmaceutical Analysis and Quality Assurance GITAM Institute of Pharmacy, GITAM (Deemed to be University), Visakhapatnam, Andhra Pradesh, India.

*Corresponding Author: Mukthinuthalapati Mathrusri Annapurna, Department of Pharmaceutical Analysis and Quality Assurance GITAM Institute of Pharmacy, GITAM (Deemed to be University), Visakhapatnam, Andhra Pradesh, India.

Received: June 21, 2019; Published: July 18, 2019

DOI: 10.31080/ASPS.2019.03.0344

\section{Abstract}

Four new spectrophotometric methods have been proposed for the determination of Bumetanide tablets using phosphate buffer pH 3.6, phosphate buffer pH 2.0, hydrochloric acid and distilled water. Shimadzu UV-1800 Model UV-VIS spectrophotometer double beam was used for the study. Bumetanide has shown linearity $1-60 \mu \mathrm{g} / \mathrm{ml}$ in all the reagents. The linear regression equations were found to be $y=0.012 x-0.010\left(R^{2}=0.999\right), y=0.063 x+0.028\left(R^{2}=0.999\right), y=0.061 x+0.047\left(R^{2}=0.999\right)$ and $y=0.012 x-0.003\left(R^{2}\right.$ $=0.999$ ) respectively in phosphate buffer $\mathrm{pH} 3.6$, phosphate buffer $\mathrm{pH}$ 2.0, hydrochloric acid and distilled water and all the methods were validated as per ICH guidelines. The methods were found to be precise, simple, and accurate and can be applied successfully for the determination of Bumetanide in tablets.

Keywords: Zero order spectroscopy (D0); Bumetanide, phosphate buffer; Hydrochloric acid; Validation; ICH guidelines

\section{Introduction}

Bumetanide (Figure 1) is used to reduce extra fluid (edema) in the body caused by conditions such as heart failure, liver disease, and kidney disease [1]. Bumetanide was patented in 1968 and came into medical use in 1972 and it is also available as a generic medication. Bumetanide was determined by different analytical methods such as HPLC [2-3], HPTLC (4), LC-MS [5], UPLC [6], spectrophotometry [7], automated flow injection with fluorimetric detection [8], amperometric detection [9] and also in biological fluids [10-11] and with and where as a very few methods were developed for its assay in pharmaceuticals using. In the present study the authors have developed a robust and economic stability indicating method for the quantification of Bumetanide in tablets. The method was validated as per ICH guidelines [12].

\section{Materials and Method}

Shimadzu double beam UV-VIS spectrophotometer (Model No. UV-1800) with quartz cells was used for the study and the solutions were scanned (200-400 nm). Bumetanide is available as tables with brand names Bumex (Validus pharmaceuticals LLC) (Genentech, Inc.) (Labelled claim: 1 and $0.5 \mathrm{mg}$ ), Burinex (Labelled claim: $2 \mathrm{mg} / \mathrm{mL}$ ) (Leo pharma).<smiles>CCCCNc1cc(C(=O)O)cc(S(N)(=O)=O)c1Oc1ccccc1</smiles>

Figure 1: Chemical structure of Bumetanide

\section{Preparation of solutions}

Solutions such as phosphate pH 3.6, phosphate pH 2.0 and 0.1 $\mathrm{N}$ hydrochloric acid were prepared as per IP 2010. Stock solution of Bumetanide was prepared by dissolving $25 \mathrm{mg}$ of Bumetanide in $25 \mathrm{ml}$ volumetric flask with methanol $(1000 \mu \mathrm{g} / \mathrm{ml})$ and further working standard solutions $(100 \mu \mathrm{g} / \mathrm{ml})$ were prepared by diluting the stock solution with phosphate $\mathrm{pH} 3.6$, phosphate $\mathrm{pH}$ 2.0, 0.1 $\mathrm{N}$ hydrochloric acid and distilled water for Method A, B, C and D respectively. Bumetanide tablets of two different brands were procured and extracted with methanol followed by dilutions and assay was performed. 


\section{Method validation}

Linearity

A series of Bumetanide solutions 1-60 $\mu \mathrm{g} / \mathrm{ml}$ were prepared in phosphate $\mathrm{pH}$ 3.6, phosphate $\mathrm{pH}$ 2.0, $0.1 \mathrm{~N}$ hydrochloric acid and distilled water from the stock solution and scanned (200-400 nm) against reagent blank. The absorption spectrum has shown maximum absorbance $\left(\lambda_{\max }\right)$ at $336.21,346.19,345.02$ and $345.13 \mathrm{~nm}$ in phosphate $\mathrm{pH}$ 3.6, phosphate $\mathrm{pH}$ 2.0, $0.1 \mathrm{~N}$ hydrochloric acid and distilled water for Method A, B, C and D respectively. The absorbance of all the solutions were noted at their $\lambda_{\max }$ and calibration curves were drawn taking concentration on the $\mathrm{x}$-axis and the corresponding absorbance on the $\mathrm{y}$-axis for Method A, B, C and D respectively.

\section{Precision and accuracy studies}

The intra-day and inter-day precision studies were executed at three different concentration levels and accuracy studies were carried out by standard addition method (50\%, 100\%, and 150\%). The \% recovery was calculated for all techniques Method A, B, C and D.

\section{Assay of Bumetanide tablets}

Twenty Bumetanide tablets were weighed accurately, powdered and powder equivalent to $25 \mathrm{mg}$ of Bumetanide was extracted with methanol in a $25 \mathrm{ml}$ volumetric flask and dilutions were made using phosphate $\mathrm{pH} 3.6$, phosphate $\mathrm{pH}$ 2.0, $0.1 \mathrm{~N}$ hydrochloric acid and distilled water. The assay was carried out using the above analytical techniques and the percentage recovery was calculated.

\section{Results and Discussion}

Four new spectrophotometric methods have been developed for the assay of Bumetanide tablets. The previously published analytical methods were compared with the present proposed methods in (Table 1). The absorption spectra obtained (Figure 2) for $\mathrm{Bu}-$ metanide has shown $\lambda \max$ at 336.21, 346.19, 345.02 and 345.13 nm in phosphate pH 3.6 (Method A), phosphate pH 2.0 (Method B), $0.1 \mathrm{~N}$ hydrochloric acid (Method C) and distilled water (Method D) respectively. Bumetanide obeys Beer-Lambert's law (Figure 3) over the concentration range $1-60 \mu \mathrm{g} / \mathrm{ml}$ in Method A, B, C and D (Table 2) and the linear regression equations were found to be $y$ $=0.012 \mathrm{x}-0.010\left(\mathrm{R}^{2}=0.999\right), \mathrm{y}=0.063 \mathrm{x}+0.028\left(\mathrm{R}^{2}=0.999\right), \mathrm{y}=$ $0.061 x+0.047\left(R^{2}=0.999\right)$ and $y=0.012 x-0.003\left(R^{2}=0.999\right)$ respectively. The percentage RSD in precision and accuracy studies in all the four methods was found to be less than 2 indicating that the methods are precise (Table 3 ) and accurate (Table 4). The optical characteristics and the assay results of Bumetanide in all the four methods were given in (Table 5).
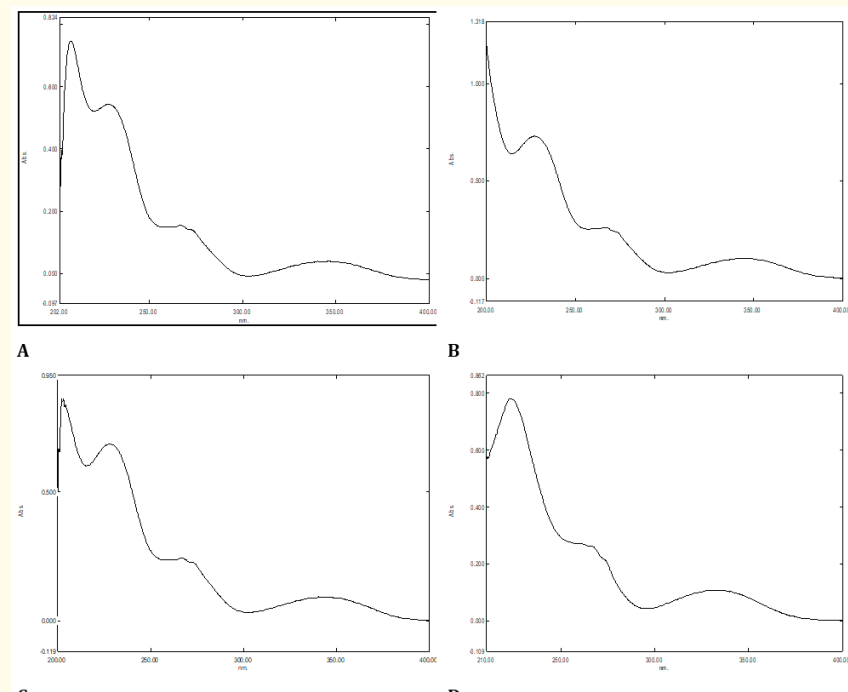

c D

Figure 2: Absorption spectra of Bumetanide (A) Phosphate buffer pH 3.6 (B) Phosphate buffer pH 2.0 (C) $0.1 \mathrm{~N} \mathrm{HCl}(\mathrm{D})$ Water
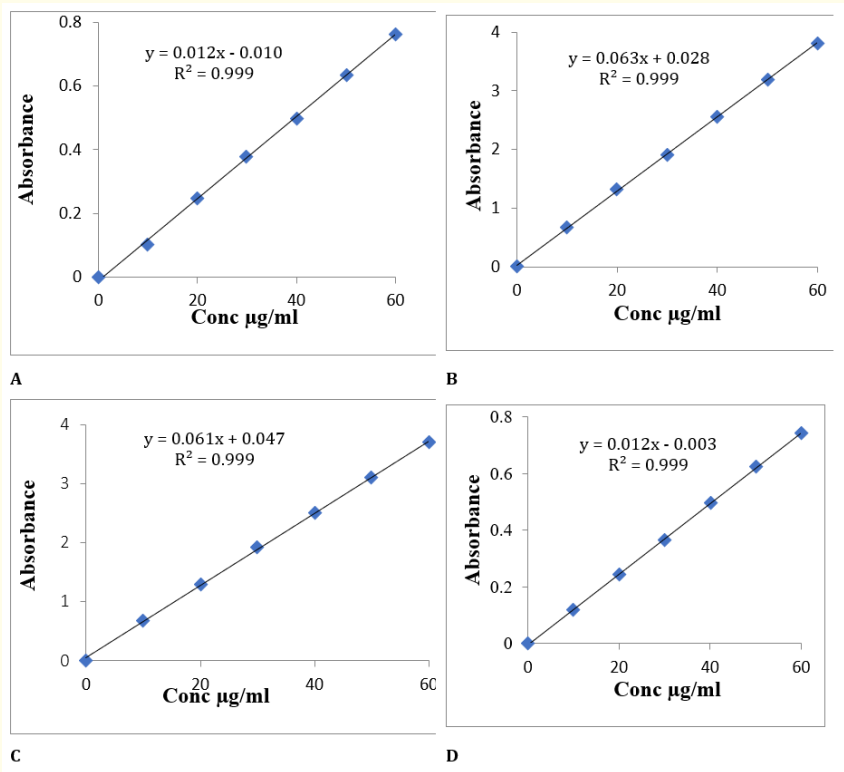

Figure 3: Calibration curves of of Bumetanide (A) Phosphate buffer pH 3.6 (B) Phosphate buffer $\mathrm{pH} 2.0$ (C) $0.1 \mathrm{~N} \mathrm{HCl}(\mathrm{D})$ Water 


\begin{tabular}{|c|c|c|c|}
\hline Reagent & $\lambda(\mathrm{nm})$ & $\begin{array}{c}\text { Linearity } \\
(\mu \mathrm{g} / \mathrm{ml})\end{array}$ & Reference \\
\hline $\begin{array}{l}\text { Borate buffer }(\mathrm{pH} 9.0) \\
\text { Phosphate buffer }(\mathrm{pH} \\
7.0)\end{array}$ & 252 & $5.0-75$ & 7 \\
\hline $\begin{array}{l}\text { Phosphate buffer pH } 3.6 \\
\text { Phosphate buffer pH } 2.0 \\
\text { Hydrochloric acid Water }\end{array}$ & $\begin{array}{l}336.21 \\
346.19 \\
345.02 \\
345.13\end{array}$ & $1-60$ & $\begin{array}{l}\text { Present } \\
\text { method }\end{array}$ \\
\hline
\end{tabular}

Table 1: Literature survey of spectrophotometric methods for Bumetanide.

\begin{tabular}{|l|c|c|c|c|}
\hline \multirow{2}{*}{ Conc. $(\mu \mathrm{g} / \mathrm{ml})$} & \multicolumn{4}{|c|}{ Absorbance at $\lambda_{\max }$} \\
\cline { 2 - 5 } & A & B & C & D \\
\hline 0 & 0 & 0 & 0 & 0 \\
\hline 10 & 0.105 & 0.669 & 0.68 & 0.121 \\
\hline 20 & 0.245 & 1.321 & 1.3 & 0.242 \\
\hline 30 & 0.381 & 1.92 & 1.91 & 0.366 \\
\hline 40 & 0.5 & 2.57 & 2.5 & 0.497 \\
\hline 50 & 0.636 & 3.2 & 3.1 & 0.625 \\
\hline 60 & 0.763 & 3.8 & 3.7 & 0.741 \\
\hline
\end{tabular}

Table 2: Linearity of Bumetanide.

\begin{tabular}{|c|c|c|c|c|}
\hline \multirow{3}{*}{ Conc. $\mathrm{g} / \mathrm{ml}$} & \multicolumn{4}{|c|}{ Inter day precision } \\
\hline & \multicolumn{4}{|c|}{ * Mean \pm Standard deviation (\% RSD) } \\
\hline & $\mathbf{A}$ & B & C & D \\
\hline 10 & $0.106 \pm 0.001(0.943)$ & $0.66 \pm 0.001(0.149)$ & $0.67 \pm 0.001(0.149)$ & $0.122 \pm 0.001(0.819)$ \\
\hline 20 & $0.246 \pm 0.002(0.609)$ & $1.32 \pm 0.001(0.075)$ & $1.31 \pm 0.01(0.763)$ & $0.243 \pm 0.001(0.411)$ \\
\hline 60 & $0.764 \pm 0.001(0.130)$ & $3.81 \pm 0.01(0.262)$ & $3.71 \pm 0.01(0.269)$ & $0.742 \pm 0.002(0.202)$ \\
\hline \multicolumn{5}{|c|}{ Intraday precision } \\
\hline 10 (Day 1 ) & $0.106 \pm 0.001(0.943)$ & $0.668 \pm 0.001(0.149)$ & $0.67 \pm 0.001(0.149)$ & $0.122 \pm 0.001(0.819)$ \\
\hline 10 (Day 2) & $0.107 \pm 0.001(0.934)$ & $0.670 \pm 0.001(0.142)$ & $0.68 \pm 0.001(0.147)$ & $0.123 \pm 0.001(0.813)$ \\
\hline 10 (Day 3) & $0.105 \pm 0.001(0.952)$ & $0.669 \pm 0.001(0.149)$ & $0.69 \pm 0.001(0.144)$ & $0.124 \pm 0.001(0.806)$ \\
\hline 20 (Day 1) & $0.246 \pm 0.002(0.609)$ & $1.322 \pm 0.001(0.075)$ & $1.31 \pm 0.01(0.763)$ & $0.243 \pm 0.001(0.411)$ \\
\hline 20 (Day 2) & $0.245 \pm 0.002(0.612)$ & $1.342 \pm 0.001(0.074)$ & $1.33 \pm 0.01(0.751)$ & $0.244 \pm 0.001(0.409)$ \\
\hline 20 (Day 3) & $0.248 \pm 0.002(0.604)$ & $1.332 \pm 0.001(0.075)$ & $1.32 \pm 0.01(0.757)$ & $0.242 \pm 0.001(0.413)$ \\
\hline 60 (Day 1) & $0.764 \pm 0.001(0.130)$ & $3.8 \pm 0.01(0.262)$ & $3.71 \pm 0.01(0.269)$ & $0.742 \pm 0.002(0.202)$ \\
\hline 60 (Day 2) & $0.763 \pm 0.001(0.131)$ & $3.83 \pm 0.01(0.261)$ & $3.73 \pm 0.01(0.268)$ & $0.743 \pm 0.002(0.201)$ \\
\hline 60 (Day 3) & $0.765 \pm 0.001(0.130)$ & $3.84 \pm 0.01(0.260)$ & $3.74 \pm 0.01(0.267)$ & $0.744 \pm 0.002(0.201)$ \\
\hline
\end{tabular}

Table 3: Precision studies of Bumetanide.

\begin{tabular}{|c|c|c|c|c|c|c|}
\hline \multirow{2}{*}{$\begin{array}{l}\text { Spiked Conc. } \\
\qquad(\mu \mathrm{g} / \mathrm{ml})\end{array}$} & \multirow{2}{*}{$\begin{array}{l}\text { Formu lation } \\
(\mu \mathrm{g} / \mathrm{ml})\end{array}$} & \multirow{2}{*}{$\begin{array}{l}\text { Total Conc. } \\
(\mu \mathrm{g} / \mathrm{ml})\end{array}$} & \multicolumn{4}{|c|}{${ }^{*}$ Conc. obtained $(\mu \mathrm{g} / \mathrm{ml})$ [\% Recovery] } \\
\hline & & & $\mathbf{A}$ & B & C & D \\
\hline $10(50 \%)$ & $\begin{array}{l}20 \\
20 \\
20\end{array}$ & $\begin{array}{l}30 \\
30 \\
30\end{array}$ & $29.86(99.53)$ & $29.86(99.53)$ & $29.86(99.53)$ & $29.86(99.53)$ \\
\hline $20(100 \%)$ & $\begin{array}{l}20 \\
20 \\
20\end{array}$ & $\begin{array}{l}40 \\
40 \\
40\end{array}$ & 39.87 (99.67) & 39.87 (99.67) & $39.87(99.67)$ & $39.87(99.67)$ \\
\hline $30(150 \%)$ & $\begin{array}{l}20 \\
20 \\
20\end{array}$ & $\begin{array}{l}50 \\
50 \\
50\end{array}$ & $50.03(100.06)$ & $49.97(99.94)$ & $49.73(99.46)$ & $49.82(99.64)$ \\
\hline
\end{tabular}

Table 4: Accuracy studies of Bumetanide. 


\begin{tabular}{|c|c|c|c|c|}
\hline Parameters & $\mathbf{A}$ & B & C & D \\
\hline Linearity range $(\mu \mathrm{g} / \mathrm{ml})$ & $1-60$ & $1-60$ & $1-60$ & $1-60$ \\
\hline$\lambda_{\max }(\mathrm{nm})$ & 336.21 & 346.19 & 345.02 & 345.13 \\
\hline Molar extinction coefficient (Litre/mole $/ \mathrm{cm}$ ) & 3826.3785 & 24379.4973 & 24780.356 & 4409.4457 \\
\hline Sandell's sensitivity ( $\mu \mathrm{g} / \mathrm{cm}^{2} / 0.001$ absorbance unit) & 0.09524 & 0.01495 & 0.01471 & 0.08265 \\
\hline Slope & 0.012 & 0.063 & 0.061 & 0.012 \\
\hline Intercept & -0.010 & 0.028 & 0.047 & -0.003 \\
\hline Correlation coefficient & 0.999 & 0.999 & 0.999 & 0.999 \\
\hline $\begin{array}{l}\text { Inter day Precision (\%RSD) } \\
\text { Intraday Precision (\%RSD) }\end{array}$ & $\begin{array}{l}0.13-0.943 \\
0.13-0.952 \\
\end{array}$ & $\begin{array}{l}0.075-0.262 \\
0.074-0.202\end{array}$ & $\begin{array}{l}0.149-0.763 \\
0.144-0.757\end{array}$ & $\begin{array}{l}0.202-0.819 \\
0.201-0.806 \\
\end{array}$ \\
\hline Accuracy (\%RSD) & 99.53-100.06 & 99.53-99.94 & $99.46-99.67$ & 99.53-99.67 \\
\hline Assay (\%) & 99.83-99.91 & 99.78-99.89 & 99.81-99.93 & 99.59-99.98 \\
\hline
\end{tabular}

Table 5: Optical characteristics of Bumetanide.

\section{Assay of Bumetanide tablets}

Assay was performed by extracting the Bumetanide with methanol from two different brands and it was found that Bumetanide was 99.45-99.72 in the two marketed formulations selected in all the spectrophotometric techniques.

\section{Conclusion}

The spectrophotometric techniques were validated as per ICH guidelines and found to be simple, precise, accurate and economical for the routine analysis of Bumetanide tablets.

\section{Acknowledgement}

The authors are grateful to M/s GITAM (Deemed to be University), Visakhapatnam for providing the research facilities and Genentech, Inc. (India) for supplying gift samples of Bumetanide. The authors declare no conflict of interest.

\section{Bibliography}

1. Feit PW. "Aminobenzoic acid diuretics. 2. 4-Substituted3-amino-5-sulfamoyl benzoic acid derivatives". Journal of Medicinal Chemistry 14.5 (1971): 432-439.

2. Rao JR., et al. "Stability indicating RP- HPLC method for Bumetanide in bulk drug and tablet formulation". Asian Journal of Research Chemistry 2.3 (2009): 266-269.

3. Huang Qin., et al. "HPLC determination of the dissolution of Bumetanide tablets". Chinese Journal of Pharmaceutical Analysis 27.8 (2007): 1285-1287.
4. Mohan Kumar., et al. "Development and validation of a stability-indicating HPTLC method for analysis of Bumetanide in the bulk drug and tablet dosage form". Research Journal of Pharmacy and Technology 3.1 (2010): 239-243.

5. Dinesh SP., et al. "Application of a rapid and sensitive liquid chromatography-tandem mass spectrometry method for determination of Bumetanide in human plasma for a bioequivalence study". Journal of Pharmaceutical and Biomedical Analysis 66 (2012): 365-370.

6. Chaitanya B., et al. "Method development, validation and stability studies for determination of Bumetanide in bulk and pharmaceutical dosage form by RP-UPLC". International Journal of Pharmacy and Pharmaceutical Sciences 10.3 (2018): 35-42.

7. Chaitanya B., et al. "Method development and validation of Bumetanide by UV spectrophotometric method in bulk and pharmaceutical dosage form". European Journal of Biomedical and Pharmaceutical Sciences 5.3 (2018): 443-450.

8. Solich P., et al. "Automated flow injection fluorimetric determination and dissolution studies of Bumetanide in pharmaceuticals". Analytica Chimica Acta 438. 1-2 (2001): 131-136.

9. Legorburu MJ., et al. "Quantitative determination of the loop diuretic Bumetanide in urine and pharmaceuticals by highperformance liquid chromatography with amperometric detection". Journal of Chromatographic Science 39.10 (2001) 425-430. 
10. Wells TG., et al. "Measurement of Bumetanide in plasma and urine by High-performance liquid chromatography and application to Bumetanide disposition". Journal of Chromatography 570.1 (1991): 235-242.

11. Smith DE. "High-performance liquid chromatographic assay for Bumetanide in plasma and urine". Journal of Pharmaceutical Sciences 71.5 (1982): 520-523.

12. ICH Validation of analytical procedures: Text and methodology Q2 (R1), International Conference on Harmonization (2005).

Volume 3 Issue 8 August 2019

(C) All rights are reserved by Mukthinuthalapati

Mathrusri Annapurna., et al. 